\title{
Refuerzo a cortante de ménsulas con polímeros reforzados con fibra de carbono (CFRP)
}

\author{
Shear Strengthening of Corbels with Carbon Fibre Reinforced \\ Polymers (CFRP)
}

\author{
S. Ahmad(*), A. Shah ${ }^{(* *)}$, A. Nawaz ${ }^{(*)}$, K. Salimullah(***)
}

Recepción/Received: 18-I-2009

Aceptación/Accepted: 2-V-2009

Publicado online/Online publishing: 11-VIII-2010

\section{RESUMEN}

Las ménsulas constituyen lo que conocemos como regiones de "distorsión" en las estructuras de hormigón, zonas en que pueden preverse roturas por cortante debido a las bajas relaciones luz de cortante-canto presentes en ellas. La concentración de solicitaciones producida por el peso de las vigas sobre superficies de carga muy reducidas en las ménsulas a menudo provoca el agrietamiento de puentes y otras estructuras de obra civil. En la literatura especializada sobre el refuerzo a cortante de las ménsulas existen escasos ejemplos de estudios experimentales. Para la presente investigación se han realizado ensayos con nueve elementos de este tipo. Dos de ellos no incluían polímeros reforzados con fibra de carbono (CFRP), mientras que los siete restantes llevaban láminas externas de CFRP, dispuestas siguiendo distintas configuraciones espaciales. Los resultados indican que la configuración y la disposición geométrica de los CFRP repercuten directamente en su resistencia a cortante, que ha resultado ser superior en todas las ménsulas reforzadas con CFRP que en las probetas de control. Los valores más altos de resistencia se han registrado en las probetas en las que la superficie más solicitada por el esfuerzo cortante estaba totalmente confinada por CFRP.

Palabras clave: región de distorsión, rotura por cortante, relación luz de cortante-canto, láminas de CFRP.

\section{SUMMARY}

Corbels constitute what are known as "disturbed" regions in concrete structures, where typical shear failure may be anticipated on the grounds of small shear span-to-depth ratios. The concentration of stress induced by the weight of girders on the very small loadbearing areas in corbels often causes cracking in bridges and other structures. Little experimental research can be found in the literature on the shear strengthening of corbels. In the present study, nine such members were tested. Two had no carbon fibre reinforced polymers attached, while CFRP laminates were externally bonded to the other seven, in a number of different spatial arrangements. Ultimate shear strength was found and compared for all specimens. The results showed that CFRP configuration and geometry directly affected corbel shear strength, which was higher in all the CFRPstrengthened corbels than in the controls. The highest strength values were recorded for specimens whose shear-critical area was wrapped in CFRP.

Keywords: disturbed region, shear failure, shear spanto-depth ratio, CFRP laminates.

(*) University Taxila (Pakistan).

(**) Allama Iqbal Open University (Pakistan).

(***) Hazara University (Pakistan). 


\section{INTRODUCCIÓN}

\subsection{Refuerzo a cortante de vigas de hormigón armado con CFRP}

Se han utilizado polímeros reforzados con fibra (FRP) para aumentar la resistencia de elementos estructurales de hormigón, acero y madera con el objetivo de:

- mejorar la capacidad resistente, especialmente en edificios muy altos y puentes, debido a cambios funcionales,

- adecuar una estructura para cumplir los códigos de construcción como resultado de modificaciones en las hipótesis de diseño,

- reforzar una estructura para que soporte posibles episodios sísmicos (mayor ductilidad y capacidad resistente) en zonas de riesgo,

- adaptar una estructura a las modificaciones previstas para su reutilización y remodelación,

- rectificar errores de diseño o construcción, especialmente durante la ejecución de vigas de puentes, y

- aumentar su durabilidad.

Los FRP pueden presentarse en forma de láminas de fibra de vidrio o de carbono. El uso de sistemas FRP implica las siguientes ventajas (1):

- un peso específico bajo (entre 150 y $900 \mathrm{~g} / \mathrm{m}^{2}$ ),

- perfiles finos (aproximadamente 0,5-1,5 mm/lámina),

- sencillez de aplicación debido a su ligereza,

- un módulo de elasticidad alto (el carbono tiene un módulo superior al del acero),

- excelente comportamiento frente a la fatiga,

- una buena relación resistencia/peso, gran resistencia a la corrosión, y

- compatibilidad con diversos acabados o revestimientos de enlucido.

El refuerzo externo de las estructuras mediante chapas metálicas se ha estudiado desde los años sesenta del siglo pasado (2) y el empleo de este método se ha extendido mucho durante las dos últimas décadas. La utilización de polímeros para reforzar las estructuras de hormigón, en cambio, es una práctica relativamente reciente (3).

Inicialmente, el uso de estos compuestos en las estructuras de hormigón y en la ingeniería civil en general se vio limitado por el alto coste de los polímeros reforzados con fibra de carbono (CFRP) y la carencia de experiencia práctica. Durante sus primeros años de vida, se destinaron esencialmente a la fabricación de aviones y armas. Sin embargo, debido al encogimiento de estos sectores a finales de la década de los ochenta y comienzos de la década de los noventa del siglo XX como resultado del final de la Guerra Fría, los fabricantes empezaron a buscar mercados

\section{INTRODUCTION}

\subsection{Shear strengthening of reinforced concrete beams with CFRP}

Fibre reinforced polymers (FRP) have been used to strengthen and retrofit concrete, steel and wood structural members to:

- enhance load carrying capacity, particularly in highrise buildings and bridges, due to a change in usage,

- $\quad$ upgrade structures to comply with building codes as a result of changes in design assumptions,

- strengthen structures to withstand possible seismic events (greater bearing capacity and ductility) in seismic risk areas,

- adapt to alterations in the intended structural form for re-use and remodelling,

- rectify design or construction errors, particularly when launching heavy bridge girders,

- increase durability.

FRP are available in the form of fibreglass and carbon fibre laminates. The advantages of using FRP systems are as follows (1):

- low unit weight (ranging from 150 to $900 \mathrm{~g} / \mathrm{m}^{2}$ ),

- thin profiles (approx. 0.5-1.5mm/ply),

- ease of application as a result of their light weight,

- high E modulus (carbon has a higher modulus than steel),

- excellent fatigue behavior,

- high strength/weight ratio,

- high corrosion resistance,

- admissibility of a variety of plaster finishes or coatings.

Plate bonding has been studied as a method for externally strengthening structures since the nineteen sixties (2) and used to fortify RC structures over the last two decades. The use of composite polymers to strengthen concrete structures is a relatively new development, however (3).

Initially, the use of such composites in concrete structures and civil engineering in general was limited due to the high cost of carbon fibre reinforced polymers (CFRP) and the lack of practical expertise. In the early years, they were used primarily in aircraft and arms manufacture. With the steep decline in those industries as a result of end of the cold war in the late nineteen eighties and early nineteen nineties, however, manufacturers began to seek alternative markets for these composites, especially as a 
alternativos para estos compuestos, especialmente como materiales de construcción para rehabilitación y remodelación (4).

La fabricación a gran escala de CFRP que se ha presenciado en los últimos dos decenios para hacer frente a la creciente demanda ha provocado una disminución de los precios, haciendo que estos materiales sean competitivos con otros empleados para reforzar y rehabilitar obras de ingeniería civil. Aunque en un primer momento estos polímeros se utilizaban para aumentar la resistencia a flexotracción de los elementos estructurales (5), durante los últimos años se han venido empleando también para reforzar las estructuras de fábrica y madera a cortante (6).

Ahmad et al. (7) utilizaron compuestos CFRP como refuerzo externo para mejorar la resistencia a cortante de vigas continuas, constatando un aumento de esta última de entre un 22 y un $136 \%$ en función de la configuración espacial.

Garden et al. (8) estudiaron la longitud de anclaje óptima de las láminas de fibra de carbono para mejorar la resistencia a cortante y a flexotracción en vigas de hormigón armado.

Zhichao Zhang et al. (9) demostraron que las láminas de CFRP pueden aumentar de un modo eficaz la resistencia a cortante de vigas de gran canto sin armadura contra el cizallamiento y propusieron un método de análisis y diseño de sistemas de confinamiento con CFRP para mejorar la resistencia a cortante de vigas de gran canto.

Guadagnini et al. (10) utilizaron vigas de hormigón armado (HA) reforzadas con CFRP con distintas relaciones luz de cortante-canto para estudiar el comportamiento a cortante de vigas reforzadas y sin reforzar. Compararon la resistencia a cortante de vigas de HA convencionales y vigas de hormigón armado y reforzadas con CFRP con el objetivo de demostrar que los principios de diseño de estas últimas pueden extrapolarse a elementos estructurales de hormigón reforzados con polímeros.

Sato et al. (11) estudiaron varios métodos de reforzar las vigas con CFRP, concluyendo que el confinamiento parcial en $U$ es más efectivo que la simple fijación de las láminas de polímero a los laterales de las vigas.

Tras llevar a cabo un estudio sobre la longitud óptima de las láminas de CFRP para mejorar la resistencia de la viga, el Instituto Federal Suizo de Tecnología recomendó un estudio más pormenorizado sobre esta cuestión.

Oral et al. (12) y Maalej y Bonacci (12) se centraron en el fallo por desprendimiento de los CFRP externos al examinar con detalle el estado actual de los modelos construction material for rehabilitation and retrofitting (4).

The large-scale manufacturing of CFRPs in the last two decades to meet growing demand has lowered prices that enable them to compete with other materials used to strengthen and rehabilitate civil works. Although at first these polymers were used to raise member flexural strength (5), in recent years they have been applied for shear strengthening in masonry and wood structures (6).

Ahmad et al. (7) used externally bonded CFRP composites to enhance the shear strength of continuous beams, showing that strength could be raised by 22 to $136 \%$, depending on the spatial configuration.

Garden et al. (8) studied the optimal anchorage length of carbon fibre plates to enhance shear and bending strength in RC beams.

Zhichao Zhang et al. (9) showed that CFRP laminates can effectively raise shear strength in deep beams with no web reinforcement and proposed a method for analyzing and designing an externally bonded CFRP system to improve deep beam shear strength.

Guadagnini et al. (10) used CFRP-RC beams with different shear span-to-depth ratios to study the shear behaviour of strengthened and unstrengthened beams. They compared the shear capacity in standard steelreinforced and CFRP-RC beams in an attempt to show that the design principles for the former could be extended to polymer-reinforced concrete members.

Sato et al. (11) explored a number of methods for applying CFRP to strengthen beams, reporting that the $U$-jacket scheme was more effective than merely attaching the polymer laminates to the sides of beams.

After conducting research on the effective length of CFRP for enhancing beam strength, the Swiss Federal Institute of Technology recommended further study on CFRP laminate anchorage length.

Oral et al. (12) and Maalej and Bonacci (12) explored debonding failure in CFRP attached externally to beams and provided a thorough review of the state of the art of 
analíticos para diseño de vigas CFRP y otras estructuras.

Anthony et al. (14) descubrieron que el empleo de medios de unión en polvo para fijar bandas de CFRP a las vigas no sólo resulta muy económico sino que reduce el tiempo de aplicación y el coste, siendo una opción viable en los casos en que la rapidez de instalación es una condición determinante.

No obstante, las investigaciones centradas en el refuerzo a cortante de las vigas de hormigón armado con materiales compuestos son escasas y los resultados bastante controvertidos (15).

Ahmad et al. (16) estudiaron varias configuraciones de láminas de CFRP para vigas y forjados con compuestos reforzados, así como la resistencia a flexotracción de vigas agrietadas reparadas con CFRP. Sus conclusiones destacan la efectividad de aplicar una longitud de CFRP superior a la estrictamente necesaria.

En relación con el rendimiento a cortante de las vigas de hormigón armado reforzado con compuestos de última generación, Khlaifa (17) llegó a las siguientes conclusiones:

- El confinamiento total o parcial con CFRP puede utilizarse para mejorar la resistencia a cortante en las zonas de momentos tanto negativo como positivo en vigas de hormigón armado, en T o rectangulares.

- Los sistemas CFRP pueden fallar aun cuando el nivel de tensión efectiva media es inferior a la resistencia nominal, como consecuencia del efecto de la concentración de solicitaciones o al desprendimiento de las láminas de CFRP.

- Independientemente del nivel de carga, los estribos de una viga reforzada están sometidos a menos deformación que los estribos de las probetas que carecen de dicho refuerzo.

- Los CFRP mejoran en mayor medida la resistencia a cortante en las vigas que carecen de armadura de acero a cortante que en las vigas armadas.

- La contribución a la resistencia a cortante del refuerzo externo mediante CFRP está directamente relacionada con la relación luz de cortante-canto (a/d) y parece aumentar a medida que aumenta la relación $\mathrm{a} / \mathrm{d}$.

- El incremento de la cantidad de CFRP no supone necesariamente un incremento proporcional de la resistencia a cortante de la viga.

- El refuerzo a cortante de las vigas mediante la fijación de láminas de CFRP en los laterales resulta menos eficaz que el confinamiento en $U$ de los elementos estructurales. analytical models for designing CFRP beams and other structures.

Anthony et al. (14) found that the use of the inexpensive powder-actuated fasteners to attach CFRP strips to beams to reduce application time and cost is a viable option where speed of installation is a key consideration.

Research on the shear strengthening of reinforced concrete beams with composite materials has been sparse, however, and fairly controversial (15).

Ahmad et al. (16) studied a number of CFRP laminate configurations for $R C$ beams and slabs, as well as the bending strength of cracked beams retrofitted with CFRP. They stressed the effectiveness of using more than the exactly sufficient length of CFRP.

Khlaifa (17) drew the following important conclusions on the shear performance of reinforced concrete beams strengthened with advanced composites:

- Externally bonded CFRP reinforcement can be used to enhance the shear capacity of $R C$ rectangular and $T$-beams in positive and negative moment regions.

- CFRP systems may fail at a mean effective stress level lower than nominal strength due to stress concentration or CFRP de-bonding from the concrete surface.

- At any given load level, the stirrups in a strengthened beam are under less strain than the stirrups in the control specimen.

- CFRP enhances shear strength more in beams without steel reinforcement to control shear than in beams with such reinforcement.

- $\quad$ The contribution of externally bonded CFRP reinforcement to shear capacity is influenced by the shear span-to-depth ratio $(a / d)$ and appears to rise with increasing $\mathrm{a} / \mathrm{d}$ ratio.

- $\quad$ Raising the amount of CFRP may not result in a proportional increase in the shear capacity of beams.

- Strengthening beams for shear by attaching CFRP laminates to the sides is less effective than U-wrapping members. 
Este mismo autor propuso ecuaciones para calcular el refuerzo a cortante con compuestos de CFRP de vigas de hormigón armado.

\subsection{Refuerzo a cortante de ménsulas de hormigón armado}

La función principal de las ménsulas que se utilizan en las estructuras de hormigón armado es la de transferir las cargas desde las vigas a las pilas y columnas. Dado que el brazo del momento es muy reducido, en caso de fallo, las roturas por cortante son más habituales que las de flexotracción. En las estructuras de hormigón armado, la sección afectada se denomina en ocasiones "región de distorsión" o región $D$, ya que no es posible aplicar la teoría clásica de la viga a estos elementos (18).

La investigación sobre ménsulas llevada a cabo por Campione (19) demostró que la resistencia de la ménsula depende de múltiples parámetros, entre los que se encuentran el modo de aplicación de la carga (monotónica o cíclica), la dirección de las cargas exteriores (vertical u horizontal), la relación luz de cortante-canto, la forma y las dimensiones de la ménsula y, por último, el tipo, la calidad y la disposición de la armadura de acero transversal. Varios estudios basados en experimentos genéricos (20-21) han demostrado que la resistencia y ductilidad de las ménsulas de hormigón armado mejoran, tanto si existe acero secundario como si no, cuando se usa hormigón reforzado con fibra en lugar del convencional.

Elgwady et al. (22), de la Universidad de El Cairo (Giza, Egipto), al estudiar los sistemas de refuerzo con láminas CFRP, vieron que, siempre que dichas láminas se encuentren en la posición adecuada, este tipo de refuerzos puede mejorar la resistencia de las ménsulas. Estos autores recomiendan colocar las bandas de CFRP en el extremo de la ménsula, ya que es el punto más débil y la sección en la que se originan las grietas. El grado de refuerzo que los FRP le confieren a las vigas y ménsulas depende del tipo de polímero, de la longitud del anclaje y del grosor y la resistencia a la tracción de los elementos de hormigón armado (23).

Aunque los CFRP se han utilizado a menudo durante estos últimos años como refuerzo contra los esfuerzos de flexión y cortante, hasta la fecha se han publicado muy pocas investigaciones experimentales sobre este tema (Campione (19)).

Hutchinson et al. (24) estudiaron la aplicación de sistemas de CFRP en la rehabilitación de cuatro puentes en la zona occidental de Canadá. Estos autores utilizaron el modelo de bielas y tirantes (STM) para el cálculo y la ejecución del refuerzo de ménsulas en el puente Jacques
This author also proposed design equations for shear strengthening RC beams with CFRP composites.

\subsection{Shear strengthening in RC corbels}

Corbels are used in the $R C$ structures mainly to transfer loads from girders and beams to piers and columns. As a result of the very short moment arm involved, shear rather than bending failure is the prevalent failure mode. In $R C$ structures, the area involved is sometimes called a "disturbed reign" or D-region, for standard beam theory is not applicable to such elements (18).

Research conducted on corbels by Campione (19) showed that corbel strength depends on a number of parameters, including mode of load application (monotonic or cyclic), direction of external loads (vertical or horizontal), shear span-to-depth ratio, corbel shape and dimensions and transverse steel reinforcement type, grade and arrangement. Studies based on wide-ranging experiments (20-21) have shown that reinforced concrete corbel strength and ductility, in both the presence and absence of secondary steel, are enhanced when fibre-reinforced concrete is used in place of the ordinary mix.

Working on CFRP laminate strengthening, Elgwady et al. (22) of Cairo University, Giza, Egypt, reported that, provided the CFRP is suitably positioned, such strengthening can enhance corbel capacity. These authors recommended running the CFRP strips to the very end of the corbel, which is the weakest and the area where cracks originate. The degree of strengthening afforded by FRP in beams and corbels depends on the polymer type and anchorage length, as well as reinforced concrete member thickness and tensile strength (23).

While CFRP has often been used for shear and flexural strengthening in the recent past, very little experimental research data have been published on the subject (Campione (19)).

Hutchinson et al. (24), studied the application of externally bonded CFRP to rehabilitate four bridges in Western Canada. The strut and tie model (STM) was used to design and implement corbel strengthening on Jacques Lodge Bridge. The jacked supports used prior to 
Lodge, retirando los soportes empleados antes de la aplicación de los polímeros tras el curado. Concluyeron que el tiempo de construcción necesario en el confinamiento con estos sistemas CFRP fue inferior al requerido en el caso de las técnicas de reparación convencionales.

Una revisión de la literatura especializada en el ámbito del refuerzo a cortante de vigas y ménsulas con CFRP revela que la utilización de estos compuestos para la reparación, la rehabilitación y el refuerzo de estructuras existentes de hormigón y madera se ha extendido durante los últimos años, especialmente en el caso de rehabilitación de edificios dañados por movimientos sísmicos. Además, son muchos los países en los que se está investigando activamente la utilización de estos compuestos y el desarrollo de sistemas de cálculo más racionales.

El presente trabajo estudia de forma experimental el uso de láminas de CFRP en el refuerzo a cortante de ménsulas. Para ello se han realizado pruebas con nueve ménsulas de hormigón armado que presentaban la misma configuración geométrica e idénticas resistencias a la compresión. Se adhirieron láminas de CFRP a siete de las ménsulas con el objetivo de probar distintas configuraciones de laminado. Las dos restantes sirvieron de referencia. A continuación se exponen los resultados del refuerzo a cortante de las ménsulas con compuestos CFRP.

\subsection{Aspectos económicos del uso de CFRP para el refuerzo y la rehabilitación de estructuras de hormigón}

Dado que las fibras compuestas tienen un coste bastante más elevado que otros materiales más tradicionales para el refuerzo y la rehabilitación de estructuras dañadas, esta solución no es necesariamente rentable en las situaciones más habituales. El relativo ahorro vinculado a la utilización de fibras compuestas y otros sistemas de refuerzo depende de las circunstancias concretas.

En la elección de un sistema FRP intervienen múltiples factores y para tomar la decisión final han de compararse los costes tanto a corto como a largo plazo (25). Cuando la solución idónea de refuerzo implica unos costes excesivamente altos, suele optarse por la demolición.

Para justificar el coste de un sistema FRP han de tenerse en cuenta los siguientes factores:

- costes y tiempo que deben invertirse en la demolición y costes asociados al cierre de carreteras o vías férreas,

- ubicación, época y horas del día en que tendrá que cerrarse la estructura o infraestructura en cuestión, y

- elección del sistema FRP más adecuado. applying the polymers were removed after curing. The authors reported that the construction time required to apply CFRP was shorter than for conventional repairing techniques.

A review of the literature on the shear strengthening of beams and corbels with CFRP revealed that the use of these composites for repairing, rehabilitating and strengthening of existing concrete and wooden structures has increased in recent years, particularly in the rehabilitation of earthquake damaged buildings. Active research on the use of CFRP composites and development of more rational design approaches is in progress in a number of countries.

The present study experimentally explored the use of CFRP in the shear strengthening of corbels. Nine corbels with the same geometry and concrete compressive strengths were tested. CFRP was bonded to seven of the corbels to test different laminate configurations, and the remaining two were used as controls. This paper discusses the results of shear strengthening corbels with CFRP composites.

\subsection{Cost issues in the use of CFRP for strengthening and rehabilitating concrete structures}

As a fairly expensive material for strengthening and rehabilitating damaged structures compared to more traditional steel solutions, composite fibres may not necessarily be cost effective in ordinary situations. The relative economics of the use of fibre composites and other strengthening systems depend on the circumstances.

Many factors are involved in the selection of an FRP system and both short- and long-term costs must be compared to reach a final decision (25). Demolition is an option often adopted where suitable strengthening involves overly high costs.

The following factors should be considered when justifying the cost of an FRP system:

- demolition costs and time involved and costs of closing roads or railways,

- location, season and times of day when the facility will have to be closed,

- choice of most suitable FRP system. 
Según los resultados de los estudios llevados a cabo en redes ferroviarias, el coste de reforzar con FRP es aproximadamente un $30 \%$ inferior al refuerzo con chapas de acero. En un informe (25) sobre la intervención para reforzar las columnas de un viaducto en el Reino Unido se constató que el empleo de FRP redujo los costes a la mitad y además contribuyó a lograr una ejecución más rápida de las obras y a limitar notablemente la necesidad de cerrar los carriles del puente al tráfico.

En general, los FRP resultan más económicos que las rehabilitaciones con acero (26), ya que en estas operaciones el coste del material tan solo supone un pequeño porcentaje del total y las tareas de instalación, la mano de obra y el mantenimiento suponen la mayor parte del gasto. Además, el ahorro derivado de la sencillez de instalación, manejo, almacenamiento y transporte y los beneficios económicos ligados al ciclo de vida de los FRP pueden ser mayores que la diferencia del coste de los materiales.

\section{OBJETIVOS DE LA INVESTIGACIÓN}

Los objetivos de la presente investigación son los siguientes:

- comprobar los efectos de las láminas de CFRP en la resistencia a cortante de las ménsulas,

- explorar la efectividad de las distintas configuraciones de dichas láminas en la resistencia a cortante de las ménsulas,

- estudiar los modos de rotura en varias ménsulas confinadas total o parcialmente por láminas de CFRP, y

- presentar los resultados del rendimiento de las ménsulas reforzadas externamente con CFRP.

\section{PROGRAMA EXPERIMENTAL}

\subsection{Mezcla de hormigón y configuración geométrica de las ménsulas}

Se fabricaron nueve ménsulas a tamaño real con la misma amasada de hormigón.

La dosificación nominal del hormigón en cuanto a cemento, áridos gruesos y finos fue de 1:1:2 (peso) y para los efectos de cálculo se supuso una resistencia nominal de $6.000 \mathrm{psi}$ (41 MPa). Como árido grueso se usó caliza molida de un tamaño máximo de $19 \mathrm{~mm}$, mientras que para los áridos finos se estableció un módulo de finura de 2,57. La relación agua/cemento fue de 0,50 y se empleo un cemento Pórtland ordinario de tipo CEM-I. El asentamiento medio del hormigón era de $40 \mathrm{~mm}$. Según los resultados de ensayos realizados con las probetas cilíndricas de hormigón, la resistencia a la compresión real media era de 6.100 psi.
Studies conducted on railway networks have shown that the costs of strengthening with FRP are approximately $30 \%$ lower than for equivalent steel plate strengthening. The use of FRP to strengthen columns on a road bridge in the UK was reported to halve the cost, in addition to shortening works duration and significantly reducing the need for lane closures (25).

As a rule, FRP is more economical than steel retrofitting (26), because in such operations, materials account for only a fraction of the total cost. Most of the expense is incurred in installation, labour and maintenance. Moreover, the savings stemming from ease of installation, handling, storage and transport and the life cycle cost benefits of FRP may well exceed the difference in the cost of the material.

\section{RESEARCH OBJECTIVES}

The objectives of the present research are listed below:

- to verify the effect of the CFRP on corbel shear strength,

- to explore the effectiveness of CFRP configurations on corbel shear strength,

- to study failure modes in several externally bonded CFRP corbels,

- to report on the performance of corbels strengthened with externally bonded CFRP.

\section{EXPERIMENTAL PROGRAMME}

\subsection{Concrete mix and corbel geometry}

Nine full-scale corbels were cast from the same concrete mix.

Nominal concrete batching for cement, coarse and fine aggregates was 1:1:2 (wt) and the design strength of 6000 psi (41 MPa) was assumed. The coarse aggregate was ground limestone with a maximum size of $19 \mathrm{~mm}$, while the fines had a fineness modulus of 2.57. The water/cement ratio was 0.50 and type I ordinary Portland cement was used. The concrete slump averaged $40 \mathrm{~mm}$. The actual mean compressive strength found by testing cylindrical concrete specimens was 6100 psi. 
La configuración geométrica de la ménsula y la distribución de la armadura se muestran en la Figura 1.
Corbel geometry and the reinforcement layouts are shown in Figure 1.

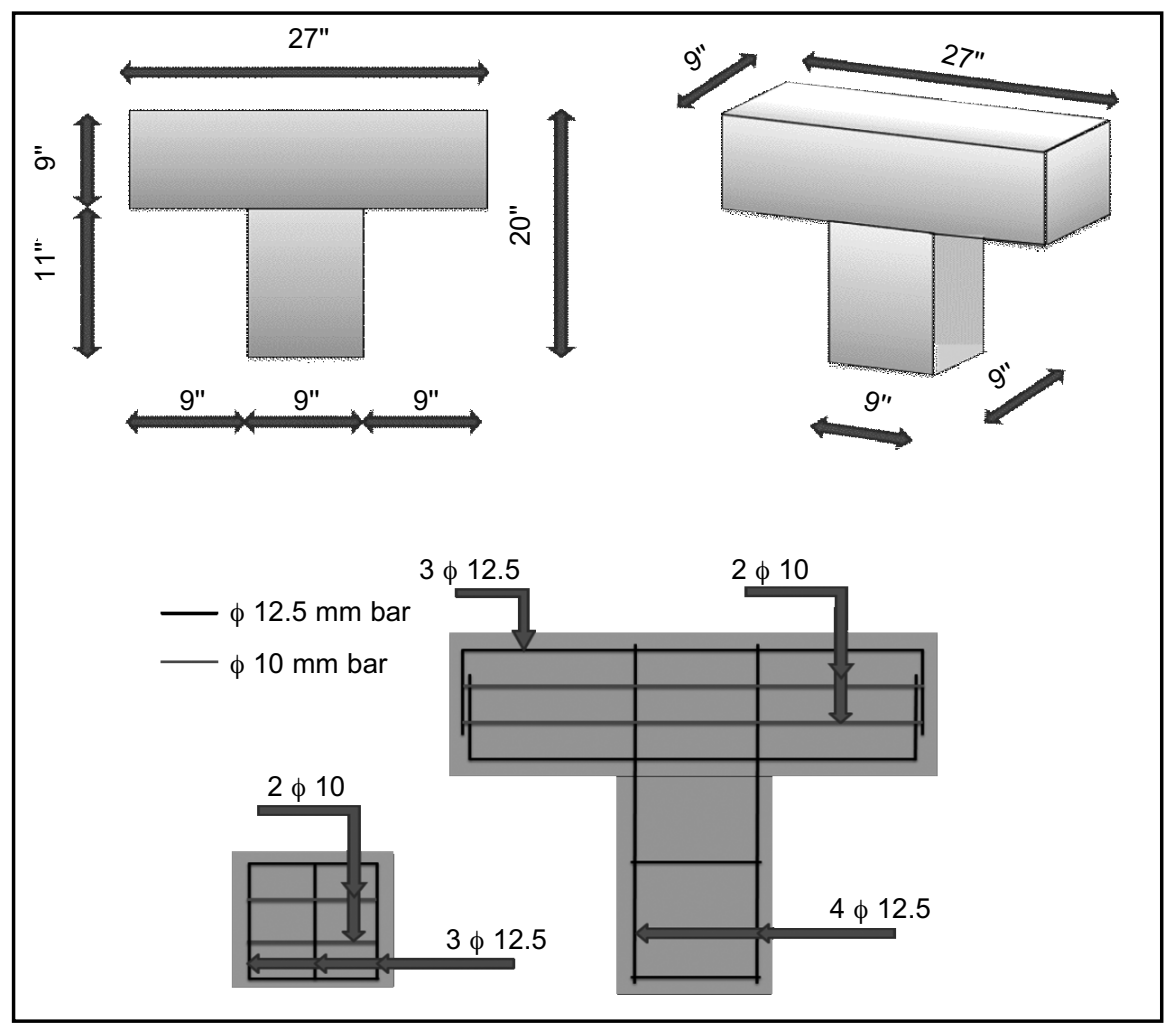

Figura 1. Detalles de la configuración geométrica de la ménsula y la armadura de acero. Figure 1. Details of corbel geometry and steel reinforcement.

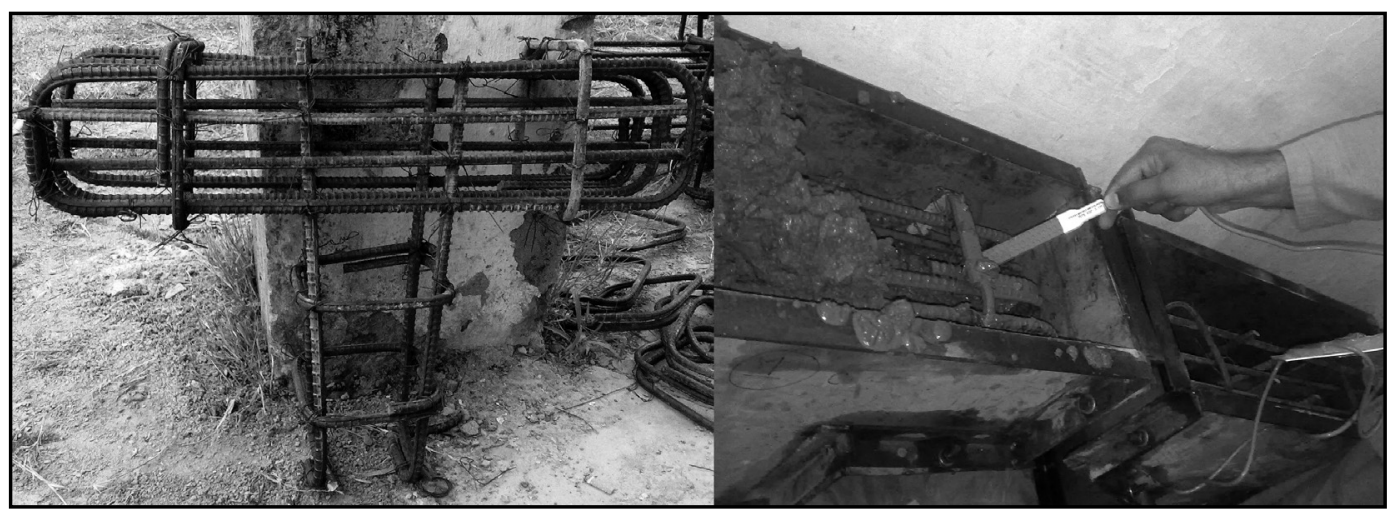

Figura 2. Detalles de la armadura (izquierda) y hormigonado de la ménsula, en la que se embebió un extensómetro a lo largo del plano de rotura previsto.

Figure 2. Details of corbel reinforcement (left) and the concrete casting operation. A strain gauge was embedded along the expected plane of failure of the corbel.

La Figura 2 muestra los detalles de armadura de la ménsula y el extensómetro que se embebió en el hormigón para registrar la deformación a lo largo del plano de rotura previsto.

Se utilizaron dos ménsulas (la CBR-01 y la CBR-02) desprovistas de CFRP como referencia y se adhirieron láminas de CFRP a las siete probetas restantes (de la CBR-03
Figure 2 depicts the corbel reinforcement details and the gauge embedded in the concrete to record strain along the expected plane of failure.

Two corbels (CBR-01 and CBR-02) devoid of CFRP were used as controls, while CFRP laminates were bonded to the seven remaining specimens (CBR-03 to CBR-09) 
a la CBR-09) siguiendo distintas configuraciones. En la Tabla 1 se muestran los materiales con las que se fabricaron las ménsulas y la disposición de las láminas de CFRP.

\subsection{Material de refuerzo}

Se humedeció el tejido de fibra de carbono unidireccional SIKA-530C para su fijación a las ménsulas. Según el fabricante, las especificaciones de las láminas son las siguientes:

Densidad de la fibra:

$$
\begin{aligned}
& 1,8 \mathrm{~g} / \mathrm{cm}^{2} \\
& 0,293 \mathrm{~mm}
\end{aligned}
$$

Resistencia a la tracción de la lámina: $3.800 \mathrm{MPa}$ Módulo de elasticidad: $231 \mathrm{GPa}$ Alargamiento máximo de rotura: using different configurations. Corbel details are given in Table 1.

\subsection{Strengthening material}

SIKA-530C uni-directional woven carbon fibre fabric was wetted for application to the corbels. The manufacturer's specifications for the laminates were as follows:

Fibre density: $1.8 \mathrm{gm} / \mathrm{sq}-\mathrm{cm}$

Sheet thickness: $0.293 \mathrm{~mm}$

Sheet tensile strength: $3800 \mathrm{MPa}$ Modulus of elasticity: $231 \mathrm{GPa}$ Maximum elongation at failure: $\quad 1.64 \%$

Tabla 1 / Table 1

Detalles del material de las ménsulas y configuración del CFRP.

\begin{tabular}{|c|c|c|c|c|c|c|}
\hline \multirow[b]{2}{*}{$\begin{array}{l}\text { Código de la } \\
\text { ménsula / } \\
\text { Corbel code }\end{array}$} & \multirow[b]{2}{*}{$\begin{array}{l}\text { Relación } \\
\text { de la mezcla / } \\
\text { Mix ratio }\end{array}$} & \multirow[b]{2}{*}{$\begin{array}{l}\text { Asentamiento } \\
(\mathrm{mm}) / \\
\text { Slump }(\mathrm{mm})\end{array}$} & \multirow[b]{2}{*}{$\begin{array}{c}\text { Resistencia a la } \\
\text { compresión a } 28 \\
\text { días de la probeta } \\
\text { cilíndrica de } \\
\text { hormigón fc psi } \\
\text { (MPa) / 28-day } \\
\text { compressive } \\
\text { strength of } \\
\text { cylindrical } \\
\text { concrete } \\
\text { specimen fc psi } \\
\text { (MPa) }\end{array}$} & \multicolumn{2}{|c|}{ Barras de acero / Steel bars } & \multirow[b]{2}{*}{$\begin{array}{l}\text { Configuración } \\
\text { del tejido FRP / } \\
\text { FRP fabric } \\
\text { configuration }\end{array}$} \\
\hline & & & & $\begin{array}{c}\text { Barras principales } \\
(\mathrm{mm}) / \text { Main bars } \\
(\mathrm{mm})\end{array}$ & $\begin{array}{c}\text { Barras } \\
\text { transversales } \\
(\mathrm{mm}) / \\
\text { Transverse bars } \\
(\mathrm{mm})\end{array}$ & \\
\hline CBR-01 & $1: 1: 2$ & 27 & $6210(42.8)$ & $2-12.5 \mathrm{~mm}$ & $2-10 \mathrm{~mm}$ & Sin CFRP / No CFRP \\
\hline CBR-02 & $1: 1: 2$ & 27 & $6210(42.08)$ & $2-12.5 \mathrm{~mm}$ & $2-10 \mathrm{~mm}$ & Sin CFRP / No CFRP \\
\hline CBR-03 & $1: 1: 2$ & 27 & $6283(43.6)$ & $2-12.5 \mathrm{~mm}$ & $2-10 \mathrm{~mm}$ & $\begin{array}{l}\text { Caras delantera y } \\
\text { trasera / Front and } \\
\text { rear faces }\end{array}$ \\
\hline CBR-04 & $1: 1: 2$ & 37 & $6283(43.6)$ & $2-12.5 \mathrm{~mm}$ & $2-10 \mathrm{~mm}$ & $\begin{array}{l}\text { Caras delantera y } \\
\text { trasera / Front and } \\
\text { rear faces }\end{array}$ \\
\hline CBR-05 & $1: 1: 2$ & 37 & $6283(42.6)$ & $2-12.5 \mathrm{~mm}$ & $2-10 \mathrm{~mm}$ & $\begin{array}{c}\text { En un ángulo de } 45^{\circ} \\
\text { con respecto a la } \\
\text { ménsula / At } 45^{\circ} \text { to } \\
\text { the corbel face }\end{array}$ \\
\hline CBR-06 & $1: 1: 2$ & 37 & $6141(42.3)$ & $2-12.5 \mathrm{~mm}$ & $2-10 \mathrm{~mm}$ & $\begin{array}{c}\text { En un ángulo de } 45^{\circ} \\
\text { con respecto a la } \\
\text { ménsula / At } 45^{\circ} \text { to } \\
\text { the corbel face }\end{array}$ \\
\hline CBR-07 & $1: 1: 2$ & 43 & $6141(42.3$ & $2-12.5 \mathrm{~mm}$ & $2-10 \mathrm{~mm}$ & $\begin{array}{c}\text { Revestimiento en U / } \\
U \text {-warp }\end{array}$ \\
\hline CBR-08 & $1: 1: 2$ & 43 & $6141(42.3)$ & $2-12.5 \mathrm{~mm}$ & $2-10 \mathrm{~mm}$ & $\begin{array}{c}\text { Revestimiento en U / } \\
U \text {-wrap }\end{array}$ \\
\hline CBR-09 & $1: 1: 2$ & 43 & $6135(42.3)$ & $2-12.5 \mathrm{~mm}$ & $2-10 \mathrm{~mm}$ & $\begin{array}{c}\text { Revestimiento } \\
\text { complete / Full wrap }\end{array}$ \\
\hline
\end{tabular}

Details of corbel material and CFRP configuration used.

Las distintas configuraciones de los CFRP se ilustran en la Figura 3.
The CFRP configurations are illustrated in Figure 3. 
Las láminas de CFRP se impregnaron con Sikadur-300, una resina de impregnación bicomponente y sin disolventes: los componentes $A$ y $B$ de la resina se mezclaron meticulosamente según una relación de 100:34,5 (en peso). Las demás especificaciones del producto se relacionan a continuación:

Temperatura de aplicación: Temperatura ambiente y del sustrato: de 15 a + $40^{\circ} \mathrm{C}$

Resistencia a la temperatura: de $-40{ }^{\circ} \mathrm{C} \mathrm{a}+60{ }^{\circ} \mathrm{C}$ Densidad:

$1,16 \mathrm{~kg} / \mathrm{l}$ ( $\mathrm{A}+\mathrm{B}$ mezclados)

Tiempo de manipulación:

Tiempo abierto:

Viscosidad: a 7 días (DIN 53455):

Módulo de flexión a 7 días (ISO 178):

Módulo de tracción a 7 días (DIN 53455):

Alargamiento de rotura a 7 días (DIN 53455):

Temperatura de termodeformación a 7 días (ASTM D648):

a $+15{ }^{\circ} \mathrm{C}$ : 6 horas y a $+40{ }^{\circ} \mathrm{C}: 90$ minutos

60 minutos

$\mathrm{a}+23{ }^{\circ} \mathrm{C}$ : $750 \mathrm{mPas}$

$\mathrm{a}+23{ }^{\circ} \mathrm{C}: 45 \mathrm{~N} / \mathrm{mm}^{2}$

$\mathrm{a}+23{ }^{\circ} \mathrm{C}: 3.000 \mathrm{~N} / \mathrm{mm}^{2}$

$\mathrm{a}+23{ }^{\circ} \mathrm{C}: 3.500 \mathrm{~N} / \mathrm{mm}^{2}$

$\mathrm{a}+23{ }^{\circ} \mathrm{C}: 1,5 \%$

$\mathrm{a}+15^{\circ} \mathrm{C}:+43{ }^{\circ} \mathrm{C}$
Resistencia a la tracción

$\mathrm{a}+23{ }^{\circ} \mathrm{C}:+49{ }^{\circ} \mathrm{C}$

$\mathrm{a}+40{ }^{\circ} \mathrm{C}:+60{ }^{\circ} \mathrm{C}$

Los pasos del proceso de aplicación de los CFRP se describen a continuación.

\section{a) Preparación de la superficie}

Se trató con chorro de arena la superficie sobre la que se iba a aplicar el CFRP y se eliminó el polvo con un aspirador. Se limpió cuidadosamente la superficie del sustrato para retirar todos los restos de polvo, materiales sueltos, grasa, aceite o cualquier otra partícula extraña. A continuación, se niveló la superficie con un relleno epoxídico.

\section{b) Mezclado del adhesivo}

Se mezclaron los dos componentes del adhesivo siguiendo la relación en peso indicada por el fabricante. El tiempo de manipulación comenzó a contarse a partir del momento en el que se mezcló la resina con el endurecedor. Cuanto mayor es la cantidad de material mezclado, menor es su tiempo de manipulación. Para prolongar el tiempo de manipulación cuando la temperatura ambiente es alta, se puede dividir la mezcla en unidades más pequeñas o se pueden enfriar los componentes antes de mezclarlos.
The CFRP laminates were wetted in Sikadur-300, a solvent-free, two component impregnation resin. Resin components $A$ and $B$ were thoroughly mixed at a ratio of 100:34.5 (wt). Other product specifications are shown below:

Application temperature range: Substrate and ambient temperature: 15 to $+40^{\circ} \mathrm{C}$

Service temperature range: $\quad-40^{\circ} \mathrm{C}$ to $+60^{\circ} \mathrm{C}$ Density:

$1.16 \mathrm{~kg} / \mathrm{l}(A+B$ mixed $)$

Pot life:

Open time:

Viscosity:

7-day tensile strength (DIN 53455):

7-day flexural modulus (ISO 178):

7-day tensile modulus (DIN 53455):

7-day elongation at failure (DIN 53455):

$+15{ }^{\circ} \mathrm{C}: 6$ hours to $+40^{\circ} \mathrm{C}$ : 90-minute $+40{ }^{\circ} \mathrm{C}: 60 \mathrm{~min}$. $+23{ }^{\circ} \mathrm{C}: 750 \mathrm{mPas}$ $+23{ }^{\circ} \mathrm{C}: 45 \mathrm{~N} / \mathrm{mm}^{2}$ $+23{ }^{\circ} \mathrm{C}: 3000 \mathrm{~N} / \mathrm{mm}^{2}$ $+23{ }^{\circ} \mathrm{C}: 3500 \mathrm{~N} / \mathrm{mm}^{2}$ $+23{ }^{\circ} \mathrm{C}: 1.5 \%$

7-day heat distortion temperature (ASTM D648):

The steps involved in applying CFRP are described below.

\section{a) Surface preparation}

The surface where the CFRP was applied was sandblasted and the dust was removed with a vacuum cleaner. The substrate surface was cleaned thoroughly to remove all dust, loose material, grease, oil and so on. The surface was then levelled with epoxy fill.

\section{b) Adhesive mixing}

The two adhesive components were mixed in the specified ratio by weight. Pot life was counted from the time resin and hardener were mixed. The greater the amount of material mixed, the shorter was the pot life. To achieve a longer pot life at high ambient temperatures, the mix may be divided into smaller units or the components cooled before mixing. 


\section{c) Aplicación del CFRP humedecido}

Dada la rugosidad del sustrato, se aplicó una imprimación adecuada, en este caso Sikadur-330, con una brocha, variándose la cantidad de imprimación necesaria entre 0,5 y $1,0 \mathrm{~kg} / \mathrm{m}^{2}$, en función precisamente de la rugosidad del sustrato.

\section{d) Colocación del tejido}

El tejido humedecido se colocó manualmente (protegiéndose el operador con guantes adecuados) en la superficie imprimada durante el tiempo abierto de la imprimación. Se extendió el tejido sobre la imprimación de resina con un rodillo plástico, trabajando en paralelo a las fibras y en una sola dirección.

\section{c) Wet CFRP application}

The rough substrate was primed by applying a suitable primer such as Sikadur-330, with a brush. The amount of primer needed ranges from 0.5 to $1.0 \mathrm{~kg} / \mathrm{m}^{2}$, depending on substrate roughness.

\section{d) Fabric placement}

The wet fabric was placed on the primed surface by hand (wearing suitable protective gloves) within the primer open time. The fabric was smoothed onto the resin primer with a plastic roller, working parallel to the fibres and in one direction only.
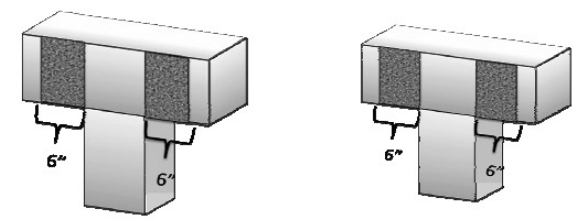

a. CBR-03 y CBR-04. CFRP solo en los laterales (adherido a la parte delantera y trasera) / a. CBR-03 and CBR-04. Side-only CFRP (bonded to front and rear)
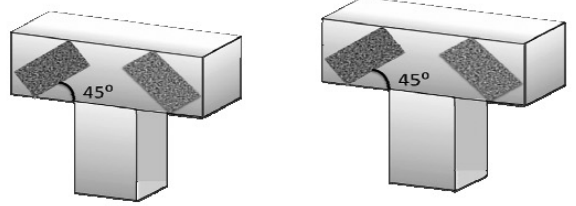

b. CBR-05 y CBR-06. CFRP solo en los laterales (adherido a la parte delantera y trasera a un ángulo de $45^{\circ}$ ) / b. CBR-05 and CBR-06. Side-only CFRP (bonded to front and rear at $45^{\circ}$ angle)
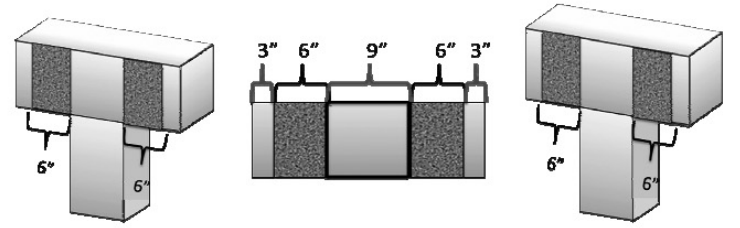

c. CBR-07 y CBR-08. Confinamiento parcial en forma de U (CFRP adherido a la parte delantera, la trasera y la inferior) / c. CBR-07 and CBR-08. U-wrapped CFRP (bonded to front, rear and bottom)
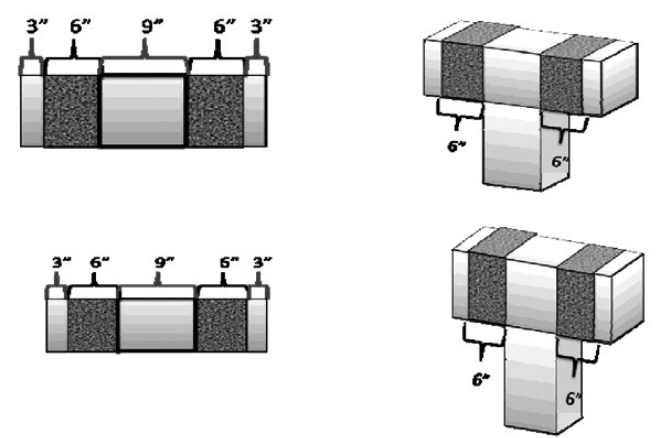

d. CBR-09. Confinamiento total (CFRP adherido a la parte delantera, la trasera, la superior y la inferior) / d. CBR-09. Fully wrapped CFRP (bonded to front, rear, top and bottom)

Figura 3. Configuración de los CFRP para las distintas probetas de ensayo. Figure 3. CFRP configuration for corbel test specimens. 


\section{ENSAYOS CON LAS MÉNSULAS Y OBSERVACIONES}

Se utilizó una prensa universal de ensayos para aplicar a la probeta una carga monotónica de $5 \mathrm{kN} / \mathrm{s}$, repartiéndose la carga equitativamente entre los dos extremos de la ménsula mediante una varilla de acero acoplada a la prensa. La varilla, apoyada sobre las placas de acero en cada punto de aplicación, distribuyó la carga sobre una superficie de $15 \times 6 \mathrm{~cm}$. En la Figura 4 se muestra el esquema del equipo de carga.

\section{CORBEL TESTING AND OBSERVATIONS}

A universal testing machine was used to apply a monotonic load at a rate of $5 \mathrm{kN} / \mathrm{sec}$. Half of this load was transferred to each end of the corbel by a steel rod fitted to the machine. Resting on bearing plates positioned at the point of application, the rod distributed the loads over a bearing area measuring $15 \times 6 \mathrm{~cm}$. A sketch of the loading apparatus is given in Figure 4.

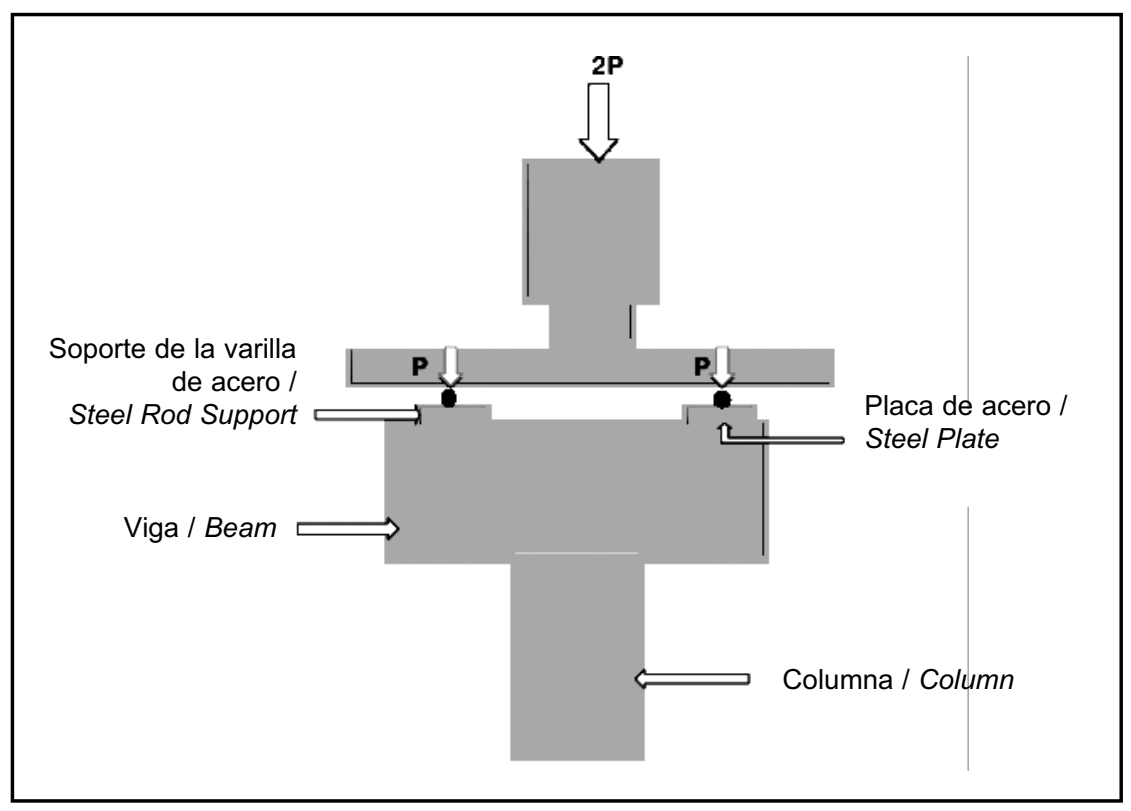

Figura 4. Dispositivo de aplicación de cargas en los extremos de la ménsula. Figure 4. Apparatus for applying loads at the ende of the corbel.

Cuando se aplicaron las cargas, alrededor de las juntas aparecieron grietas que posteriormente se extendieron hacia arriba hasta el punto de aplicación. De las múltiples grietas que se produjeron en las ménsulas sometidas a ensayo, las más destacadas y las que finalmente provocaron la rotura fueron las circundantes a las juntas, es decir, las que se encontraban en las zonas más solicitadas por el esfuerzo cortante. Los ángulos de la rotura por fisuración variaron entre los 50 y los $70^{\circ}$. En la Tabla 2 se enumeran las cargas de rotura de algunas de las ménsulas. Se consideró como resistencia a cortante de la ménsula la carga máxima transferida al punto de rotura en la zona de la ménsula solicitada por dicho esfuerzo. La resistencia a cortante de las ménsulas tratadas con CFRP se comparó con la de las probetas de control CBR01 y CBR-02 para determinar el incremento de resistencia atribuible a las láminas de CFRP fijadas externamente a las ménsulas.
When the loads were applied, cracks appeared around the joints and extended upward to the point of application. The most prominent of the many cracks appearing in the corbels tested and the ones that ultimately induced failure were the cracks around the joints, i.e., the shear-critical zones. The crack failure angles ranged from 50 to $70^{\circ}$. Table 2 lists the failure loads for several of the corbels. Corbel shear strength was taken to be the peak load transferred to the point of failure in the critical area of the corbel. The shear strength of the CFRP-treated corbels was compared to the strength of control specimens CBR-01 and CBR-02 to determine the increase in shear strength attributable to the externally bonded CFRP. 
Tabla 2 / Table 2

Incremento porcentual de la resistencia a cortante de la ménsula con respecto a las probetas de control y modo de rotura. Increase in corbel shear strength as per cent of control strength, and failure mode.

\begin{tabular}{|c|c|c|c|c|c|}
\hline $\begin{array}{l}\text { Código de la ménsula } \\
\text { / Corbel code }\end{array}$ & $\begin{array}{l}\text { Carga en la primera } \\
\text { grieta }(\mathrm{kN}) / \text { Load at } \\
\text { first crack }(k N)\end{array}$ & $\begin{array}{c}\text { Configuración } \\
\text { de los CFRP / CFRP } \\
\text { configuration }\end{array}$ & $\begin{array}{c}\text { Carga de rotura (kN) I } \\
\text { Average failure load } \\
(k N)\end{array}$ & $\begin{array}{l}\text { Incremento a cortante } \\
(\%) \text { I } \\
\text { Increase in shear (\%) }\end{array}$ & $\begin{array}{l}\text { Modo de rotura I } \\
\text { Failure mode }\end{array}$ \\
\hline CBR-1 & 274.4 & Sin CFRP / No CFRP & \multirow{2}{*}{627.42} & $\begin{array}{l}\text { Probeta de control / } \\
\text { Control specimen }\end{array}$ & $\begin{array}{l}\text { Cortante diagonal / } \\
\text { Diagonal shear }\end{array}$ \\
\hline CBR-2 & 269.5 & SDin CFRP / No CFRP & & $\begin{array}{l}\text { Probeta de control / } \\
\text { Control specimen }\end{array}$ & $\begin{array}{l}\text { Cortante diagonal / } \\
\text { Diagonal shear }\end{array}$ \\
\hline CBR-3 & 362.7 & $\begin{array}{c}\text { Caras delantera } \\
\text { y trasera / Front and } \\
\text { rear }\end{array}$ & \multirow{2}{*}{730} & 16.4 & $\begin{array}{c}\text { Cortante diagonal + } \\
\text { Rotura del CFRP / } \\
\text { Diagonal shear }+ \text { CFRP } \\
\text { rupture }\end{array}$ \\
\hline CBR-4 & 343.1 & $\begin{array}{c}\text { Caras delantera y } \\
\text { trasera / Front and rear }\end{array}$ & & & $\begin{array}{c}\text { Cortante diagonal + } \\
\text { Rotura del CFRP / } \\
\text { Diagonal shear }+ \text { CFRP } \\
\text { rupture }\end{array}$ \\
\hline CBR-5 & 299.0 & $\begin{array}{c}\text { En un ángulo de } 45^{\circ} \\
\text { con respecto a la } \\
\text { ménsula / At a } 45^{\circ} \\
\text { angle }\end{array}$ & \multirow{2}{*}{725.5} & 8.1 & $\begin{array}{c}\text { Colapso por cortante + } \\
\text { Rotura del CFRP / } \\
\text { Shear collapse }+ \text { CFRP } \\
\text { rupture }\end{array}$ \\
\hline CBR-6 & 299.0 & $\begin{array}{l}\text { En un ángulo de } 45^{\circ} \\
\text { con respecto a la } \\
\text { ménsula / At a } 45^{\circ} \\
\text { angle }\end{array}$ & & & $\begin{array}{c}\text { Colapso por cortante }+ \\
\text { Rotura del CFRP / } \\
\text { Shear collapse }+ \text { CFRP } \\
\text { rupture }\end{array}$ \\
\hline CBR-7 & 358.7 & $\begin{array}{c}\text { Confinamiento en U / } \\
\text { U-wrap }\end{array}$ & \multirow{2}{*}{779.37} & 24.21 & $\begin{array}{l}\text { Cortante diagonal + } \\
\text { desprendimiento del } \\
\text { CFRP / Diagonal shear } \\
\text { + CFRP de-bonding }\end{array}$ \\
\hline CBR-8 & 303.9 & $\begin{array}{c}\text { Confinamiento en U / } \\
\text { U-warp }\end{array}$ & & & $\begin{array}{l}\text { Cortante diagonal + } \\
\text { desprendimiento del } \\
\text { CFRP / Diagonal shear } \\
\text { + CFRP de-bonding }\end{array}$ \\
\hline CBR-9 & 392.4 & $\begin{array}{l}\text { Confinamiento } \\
\text { complete / Full wrap }\end{array}$ & 788.19 & 25.63 & $\begin{array}{c}\text { Colapso por cortante }+ \\
\text { rotura del CFRP / Shear } \\
\text { collapse }+ \text { CFRP } \\
\text { rupture }\end{array}$ \\
\hline
\end{tabular}

\subsection{Modo de rotura de las ménsulas}

\subsubsection{Probetas de control sin CFRP (CBR-01 y CBR-02)}

En las dos ménsulas la primera grieta apareció con una carga de aproximadamente $270 \mathrm{kN}$. La carga de rotura de estas dos ménsulas también fue muy similar, de unos $630 \mathrm{kN}$. La rotura por cortante se produjo a lo largo de un plano diagonal y el ángulo de rotura de ambas muestras se enmarcó en un intervalo bastante reducido: entre 65 y $75^{\circ}$ con respecto a la biela de compresión. Esta similitud en la carga de rotura y los valores de los ángulos puede atribuirse al comportamiento uniforme del hormigón armado, ya que no se colocaron polímeros reforzados con fibra en estas dos probetas. En la Figura 5 se detalla el modo de rotura de las probetas CBR- 01 y CBR-02.

\subsection{Corbel failure mode}

\subsubsection{CFRP-free control specimens (CBR-01 and CBR-02)}

The first crack appeared in the two corbels under a load of about $270 \mathrm{kN}$. The failure load for these two specimens was also very similar, at around $630 \mathrm{kN}$. Shear failure occurred along a diagonal plane and the angle of failure was reasonably close in the two specimens, at 65 to $75^{\circ}$ to the compression strut. This similarity in the failure load and angle values may be attributed to the uniform behaviour of reinforced concrete, for these two specimens were not externally bonded to fibre reinforced polymers. Figure 5 shows the failue mode in specimens CBR-01 and CBR-02. 


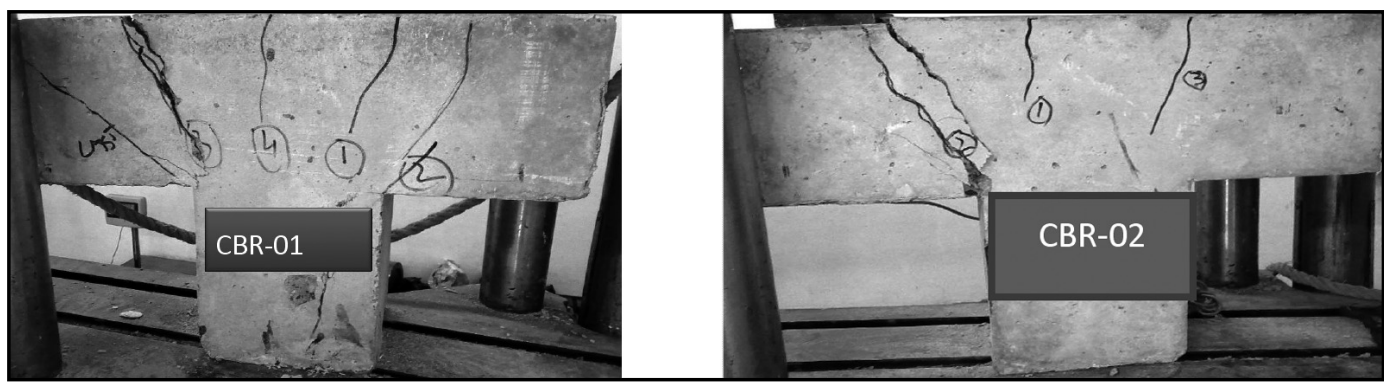

Figura 5. Modo de rotura de las ménsulas de control CBR-01 y CBR-02 (que se rompieron con prácticamente la misma carga). También hay que destacar las similitudes en el plano de rotura.

Figure 5. Mode of failure in control corbels CBR-01 and CBR-02 ( which failed under nearly the same load). Note the similarities in the plane of failure.

\subsubsection{Modos de rotura en las ménsulas reforzadas con CFRP (de la CBR-03 a la CBR-09)}

\subsubsection{Ménsulas con láminas CFRP en las caras delantera y trasera (CBR-03 y CBR-04)}

- En las ménsulas con láminas CFRP en ambas caras (delantera y trasera), el modo de rotura fue el desprendimiento de la lámina. Las cargas de rotura de las ménsulas CBR-03 y CBR-04 fueron de 784 y 676 $\mathrm{kN}$ respectivamente, es decir, la carga de rotura media fue de $730 \mathrm{kN}$. La variación en las cargas de rotura de estas dos probetas idénticas puede atribuirse esencialmente a las diferencias entre los valores de desprendimiento.

- En la probeta CBR-03, las primeras grietas por cortante aparecieron bajo las láminas de CFRP y produjeron en última instancia una rotura frágil repentina de la ménsula tras la aplicación de una carga relativamente alta. Sin embargo, en la probeta CBR-04 la grieta llegó a romper la lámina de CFRP, lo que provocó la rotura de la ménsula a un valor de carga inferior. Por lo tanto, los CFRP pueden ocultar grietas en el hormigón que no se ven hasta que se desprenda la lámina y que pueden llevar a una rotura frágil como en el caso de la probeta CBR-03. En la Figura 6 pueden verse fotografías de las probetas con roturas.

\subsubsection{Failure modes in CFRP-strengthened corbels (CBR-03 to CBR-09)}

\subsubsection{Corbels with CFRP laminates on front and rear (CBR-03 and CBR-04)}

- In corbels with CFRP laminates on both sides (front and rear), failure appeared in the form of laminate de-bonding. The failure loads for corbels CBR-03 and CBR-04 were 784 and $676 \mathrm{kN}$ respectively, or an average of $730 \mathrm{kN}$. The variation in the failure loads of two identical specimens may be attributed primarily to de-bonding differences.

- In specimen CBR-03 the first shear cracks, which appeared underneath the CFRP sheet, ultimately induced sudden and brittle corbel failure under a relatively high applied load. In CBR-04, however, the crack ruptured the CFRP laminate, causing corbel failure at a lower load value. Consequently, the CFRP may conceal cracks appearing in the concrete after de-bonding that may cause brittle failure as in specimen CBR-03. See Figure 6 for photographs of the failed specimens.

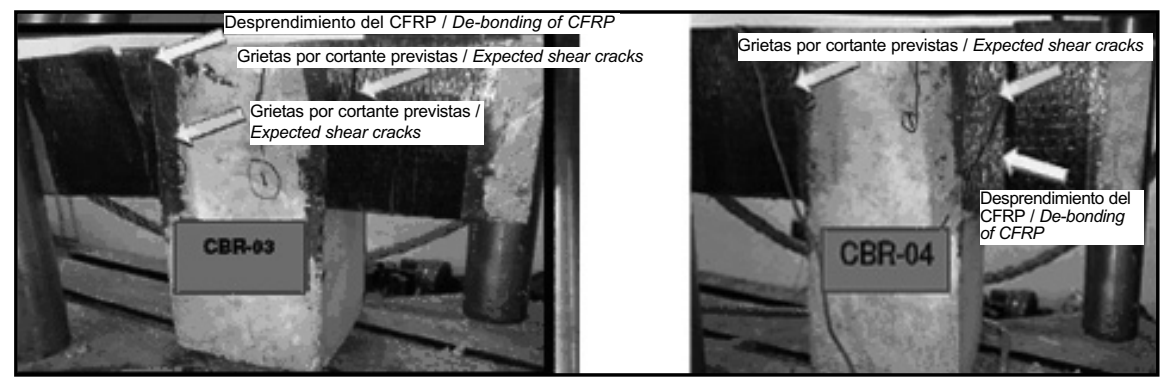

Figura 6. Rotura de las ménsulas CBR-03 y CBR-04 (con láminas CFRP adheridas a la cara delantera y trasera). Figure 6. Failure in corbels CBR-03 and CBR-04 (CFRP laminates attached to front and rear). 
4.1.2.2. Ménsulas reforzadas con láminas de CFRP colocadas a un ángulo de $45^{\circ}$ con respecto al plano de rotura (CBR-05 y CBR-06)

Se comprobó la efectividad de los CFRP para mejorar la resistencia a cortante de las ménsulas cuando las láminas se colocaron a un ángulo de $45^{\circ}$ con respecto al plano formado por la junta entre la columna y la viga. Las primeras grietas diagonales aparecieron con valores de carga prácticamente idénticos en las dos probetas. Además, ambas ménsulas se rompieron con una carga muy similar, 725 kN, debido a la rotura de la lámina y a la fisuración diagonal. Esta uniformidad puede deberse a la acción conjunta del hormigón armado y las láminas de CFRP, que cubren un área más amplia del plano de rotura previsto que en el caso anterior. Aunque la superficie de la lámina era la misma, su posición resultó ser más eficaz. La fotografía de la Figura 7 muestra la probeta CBR-05 después de la rotura.
4.1.2.2. Corbels strengthened with CFRP laminates laid at $45^{\circ}$ to the failure plane (CBR-05 and CBR-06)

CFRP effectiveness in improving corbel shear strength was also found for laminates attached at a $45^{\circ}$ angle to the plane formed by the beam - column joint. The first diagonal cracks appeared at nearly the same load values in the two specimens. Moreover, both corbels failed under approximately the same load, $725 \mathrm{kN}$, as a result of laminate rupture and diagonal cracking. Such uniformity may be due to the joint action of the reinforced concrete and CFRP laminates, which covered a larger area of the expected plane of failure than in the preceding case. Although the laminate area was the same, the position made it more effective. The photograph in Figure 7 depicts specimen CBR-05 after failure.

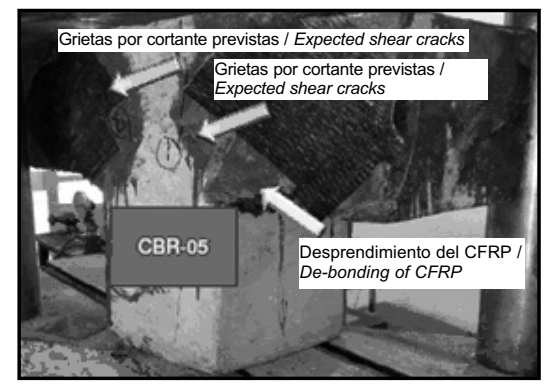

Figura 7. Rotura de la ménsula CBR-05 con láminas de CFRP a un ángulo de $45^{\circ}$. Figure 7. Failure in corbel CBR-05, with CFRP laminates at a $45^{\circ}$ angle.

4.1.2.3. Ménsulas reforzadas con láminas de CFRP adheridas a tres caras o confinamiento en forma de $U$ (CBR-07 y CBR-08)

En el caso del refuerzo por confinamiento parcial en forma de $U$, las láminas de CFRP se colocaron en los laterales y la parte inferior de las ménsulas, como se muestra en la Figura 8, cubriendo una superficie mayor que en los dos ensayos anteriores.

\subsubsection{Corbels strengthened with CFRP laminates attached to three sides or U-wrapped (CBR-07 and CBR-08)}

In U-wrap strengthening, the CFRP laminates were attached to the side and bottom of the corbels, as shown in Figure 8, covering more area than in the preceding two cases.

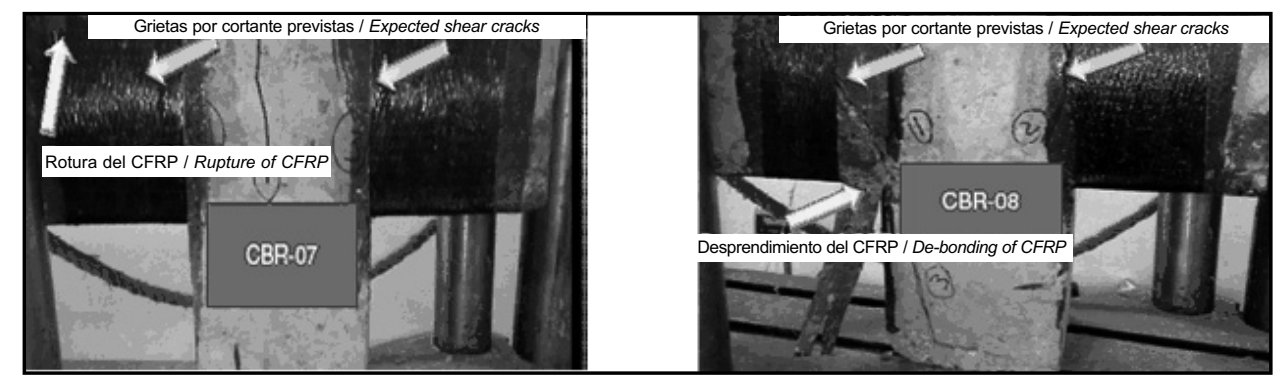

Figura 8. Rotura en las ménsulas CBR-07 y CBR-08 con revestimiento de láminas de CFRP en forma de U. Figure 8. Failure in corbels CBR-07 and CBR-08, U-wrapped in CFRP laminates.

La resistencia media de las ménsulas fue un $24 \%$ superior a la de las probetas de control y el hormigón armado y las láminas de CFRP mostraron una respuesta a las
The mean corbel strength rose by $24 \%$ compared to the controls and the reinforced concrete and CFRP laminates exhibited a more integrated response to the loads. The 
cargas más equilibrada. El comportamiento observado se asemejó al confinamiento lateral ejercido por estribos y tirantes en vigas y columnas para soportar el esfuerzo cortante. La rotura se produjo debido a las grietas diagonales en la zona solicitada a cortante y al desprendimiento de las láminas. Se obtuvo una resistencia media de las ménsulas de 779 kN. Cuando las vigas reales están reforzadas para soportar las solicitaciones de flexotracción resulta sencillo revestir en forma de $U$ la zona afectada. En cambio, la colocación de las láminas de CFRP cerca de los soportes en las ménsulas y vigas puede resultar compleja. De ahí que, a pesar de la gran efectividad del confinamiento parcial en forma de $U$, su utilización práctica en situaciones reales puede plantear dificultades para lograr un refuerzo a cortante realmente eficaz en vigas y ménsulas.

\subsubsection{Ménsulas reforzadas mediante el confinamiento completo con CFRP (CBR-09)}

La última ménsula se confinó completamente con CFRP y se halló la resistencia a compresión en una prensa de ensayos. En este caso la rotura también fue frágil y repentina y se produjo por aplastamiento. La carga de rotura fue ligeramente superior que en el caso de las probetas con un revestimiento en forma de U. Una posible explicación de que esta diferencia del valor de la resistencia sea tan reducida podría residir en que la lámina de la parte superior de la ménsula desempeñe una función secundaria o totalmente nula en su refuerzo. Otra podría ser el efecto de confinamiento del hormigón. También podría preverse un valor más alto debido a que los ensayos se han realizado con una única probeta con confinamiento total. Este último método podría revelarse como una forma efectiva de refuerzo de columnas frente a deformaciones y roturas por cortante. La Figura 9 muestra la probeta CBR-09 tras la rotura. action observed resembled the lateral confinement exerted by stirrups and ties in beams and columns to resist shear stress. Failure was induced by the diagonal cracks in the shear-critical area and laminate debonding. Average corbel strength was observed to be $779 \mathrm{kN}$. U-wrapping around the critical area in actual breams is straightforward when strengthened to resist bending stress. CFRP laminates may be difficult to install in corbels and beams near the supports. Hence, despite the greater effectiveness of U-wrapping, its practical use in real situations may pose difficulties for effective shear strengthening in beams and corbels.

\subsubsection{Corbels strengthened with fully wrapped CFRP} (CBR-09)

The last corbel was fully wrapped in CFRP and tested with the universal testing machine. Failure, here also sudden and brittle, occurred as a result of concrete crushing. The failure load was slightly higher than in the $U$-wrapped specimens. One possible explanation for the small magnitude of the difference might be that the laminate on the top of the corbel may have only a minor role or no role at all in corbel strengthening. Another might be the jacketing effect of the concrete. The higher value might also be expected because only one fully wrapped specimen was tested. Full wrapping may prove to be effective for strengthening columns against buckling and shear failure. Figure 9 shows specimen CBR-09 after failure.

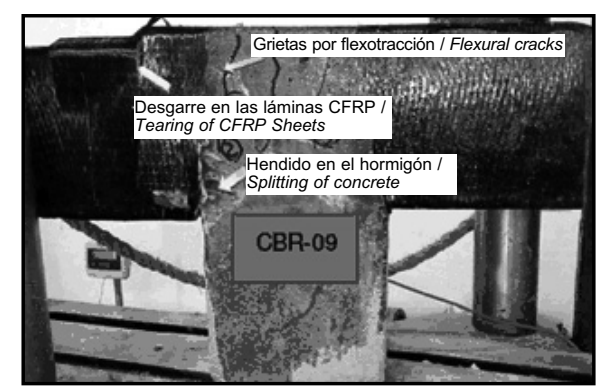

Figura 9. Rotura de la ménsula CBR-09 totalmente revestida con láminas de CFRP. Figure 9. Failure in corbel CBR-09, fully wrapped in CFRP laminates.

\subsection{Comparación de la relación carga-deformación en varias ménsulas}

Se embebieron extensómetros en una ménsula de referencia (CBR-02), en una de las ménsulas con refuerzo

\subsection{Comparison of the load-strain relationship in various corbels}

Strain gauges were embedded in the control corbel (CBR-02), one of the front and rear-strengthened corbels 
frontal y trasero (CBR-04) y en la ménsula totalmente confinado (CBR-09), orientándolos en la dirección del plano de rotura previsto según el modelo de bielas y tirantes (STM), con el objetivo de comparar la deformación en la zona susceptible al efecto del esfuerzo cortante.
(CBR-04) and the fully wrapped corbel (CBR-09) in the direction of the plane of failure predicted by the strut and tie model (STM), for comparison of strain in the shearcritical area.

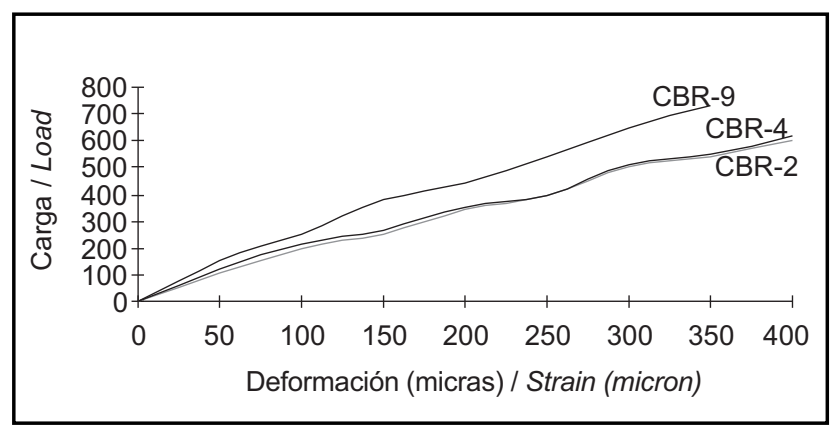

Figura 10. Comparación de la relación carga-deformación en varias ménsulas. Figure 10. Comparison of load-strain relationship for corbels.

Las relaciones carga-deformación de los tres tipos de ménsulas se muestran en la Figura 10. Las ménsulas con CFRP resultaron más rígidas que las probetas de control. Para todos los valores de deformación, las ménsulas totalmente revestidas presentan los valores de carga más altos. El hecho de que la curva de la probeta CBR09 tenga una pendiente más pronunciada se debe a que su módulo de elasticidad es superior al de las otras dos ménsulas.

\section{CONCLUSIONES}

- Se ha observado que la mayor parte de las roturas en las ménsulas de hormigón armado se producen por esfuerzos cortantes diagonales, independientemente de si llevan o no láminas de CFRP.

- Las probetas reforzadas externamente con láminas de CFRP presentan en todos los casos una resistencia a cortante superior que las probetas de referencia sin refuerzo.

- El incremento de la resistencia a cortante varía entre el 8 y el $25 \%$, en función de la disposición de las láminas con respecto al plano previsto de rotura.

- El refuerzo con CFRP aumenta la rigidez de las ménsulas y hace que las grietas diagonales aparezcan tras la aplicación de cargas muy superiores a las que han de aplicarse en el caso de las probetas de referencia.

- Las ménsulas en las que se han colocado láminas de CFRP en dos laterales, tanto en posición recta como con inclinación, han experimentado roturas cuando se ha roto el laminado debido a una longitud insuficiente del anclaje.

- En el caso del confinamiento parcial en forma de U, las láminas CFRP incrementan notablemente la resistencia
The load-strain relationships for the three types of corbels are shown in Figure 10. The CFRP-clad corbels were stiffer than the control specimens. The highest load values for any given strain value were recorded for the fully wrapped configuration. The steeper slope on the specimen CBR-09 load-strain curve meant that it had a higher modulus of elasticity than either of the other two corbels.

\section{CONCLUSIONS}

- Most of the RC corbels, CFRP-strengthened or otherwise, failed under diagonal shear.

- Specimens with externally bonded CFRP laminates had consistently higher shear strength than the unstrengthened controls.

- The increase in shear strength ranged from 8 to $25 \%$ depending on laminate configuration with respect to the expected plane of failure.

- CFRP strengthening raised corbel stiffness, with diagonal cracks appearing under much higher loads than in the control specimens.

- The corbels on which the CFRP composites were attached on two sides, whether straight or slanted, failed when the laminate ruptured due to insufficient anchorage length.

- When U-wrapped, CFRP laminates increased corbel strength substantially, although with this configuration 
de la ménsula. No obstante, con esta configuración, la rotura producida por el desprendimiento del laminado es muy frágil y repentina.

- Dado que el aumento de resistencia a cortante con confinamiento completo es escasamente superior al conseguido con el confinamiento parcial en forma de $U$, se recomienda este último para el refuerzo de ménsulas.

- Las ménsulas reforzadas con CFRP se rompen de un modo más repentino que las probetas de referencia. Cuanto mayor es la superficie de láminas CFRP, más frágil es la rotura de la ménsula. Por lo tanto, las estructuras reforzadas con CFRP deben controlarse minuciosamente para evitar roturas frágiles repentinas.

\section{RECOMENDACIONES}

Son necesarias más investigaciones experimentales para desarrollar ecuaciones empíricas, que permitan calcular el refuerzo a cortante de ménsulas mediante CFRP con el objetivo de definir la longitud mínima de anclaje de las láminas, fuera de los límites de la zona afectada por el esfuerzo cortante. failure, induced by laminate de-bonding, was very brittle and sudden.

- Since shear strength in the fully wrapped corbels rose only slightly more than in the U-wrapped specimens, $\mathrm{U}$-wrapping is the recommended arrangement for strengthening corbels.

- CFRP-strengthened corbels failed more suddenly than the unstrengthened controls. The greater the area of the CFRP laminates, the more brittle was corbel failure: consequently, CFRP-strengthened structures must be carefully monitored for sudden, brittle failure.

\section{RECOMMENDATIONS}

More experimental research is required to develop empirical equations for CFRP-mediated shear strengthening of corbels to define the minimum laminate anchorage length outside the critical area.

\section{BIBLIOGRAFÍA / BIBLIOGRAPHY}

(1) Nanni, A. (2000): "Carbon fibres in Civil Structures: Rehabilitation and New Construction". Proc., The Global Outlook for Carbon Fibre 2000, Intertech, San Antonio, Texas, December 4-6, 2000.

(2) Hermite, L. R.: "Concrete reinforced with glued steel plates". Synthetic Resins in Building Construction. Paris: RILEM International Symposium, 1967:175 to 203.

(3) Neal, K. (2000): "FRPs for structural rehabilitation: a survey of recent progress". Progress in Structural Engineering and Material, vol. 2, pp. 133-138. doi:10.1002/1528-2716(200004/06)2:2<133::AID-PSE16>3.0.CO;2-C

(4) Head, P. R. (1996): "Advanced Composites in Civil Engineering. A critical review at High interests and low use stage of development". Proceedings of Advanced Composite Material in Bridges and Structures (ACMB-2). Canadian Society of Civil Engineers Montréal Quebec.

(5) Raichie, A.; Beaudoin,Y.; Labossiere, P.: "Durability of composite material used external reinforcement of RC beams". Proceedings of Annual Conference of CSCE, CSE, Regina, pp. 155-164.

(6) Kuizik, M.; Elwi, A. E. E. and Cheng, J. R. R. (1999): "Cyclic behavior of masonry wall with FRP". Structural Engineering Report Report n० 228 University of Alberta-Edmonton-116 pp.

(7) Ahmed, K. and Antonio, N.: "Improving Shear capacity of existing RC T-Section beams using CFRP composites". Cement and Concrete Composites, vol. 22, no 2, July 2000, pp. 165-174.

(8) Garden, H. N.; Quantrill, R. J.; Hollaway, L. C.; Thorne, A. M.; Parke, G. A. R. (1998): "An experimental study of the anchorage length of carbon fibre composite plates used to strengthen reinforced concrete beams". Construction and Building Materials, vol. 12, pp. 203-219. doi:10.1016/S0950-0618(98)00002-6

(9) Zhichao Zhang; Cheng-Tzu; Thomas Hsu and Jon Moren (2004): "Shear Strengthening of Reinforced Concrete Deep Beams Using Carbon Fibre Reinforced Polymer Laminates". Journal of composites for construction, ASCE, vol. 8 (5), pp. 403-414. doi:10.1061/(ASCE)1090-0268(2004)8:5(403)

(10) Guadagnini, M.; Pilakoutas, K. and Waldron, P. (2006): "Shear Resistance of FRP RC Beams: Experimental Study". ASCE Journal of Composites for Construction, Vol. 10 (6), pp. 464-473. doi:10.1061/(ASCE)1090-0268(2006)10:6(464)

(11) Sato, Y.; Ueda T. and Yanaka, T. (1996): "Shear Reinforcement effect of Carbon Reinforced sheets attached to the sides of beams". Proceedings of Advanced Composite Material in Bridges and Structures (ACMBS-3), Canadian Society of Civil Engineers Montréal Quebec.

(12) Buyukozturk, O.; Gunes, O. and Karaca, E. (2004): "Progress on understanding de-bonding problems in reinforced concrete and steel members strengthened using FRP composites". Construction and Building Materials, vol. 18(1), pp. 9-19.

(13) Maalej, M.; and Bonacci, J. F. (1998): "Repair and Strengthening of Beams Using FRP Reinforcement". Proceedings of the 1998 CSCE Annual Conference, V. 3b, Halifax, Nova Scotia, June 10-13, pp. 643-652. 
14) Anthony J.; Lamanna, L.; Bank, C. and David W. Scott (2001): "Flexural Strengthening of Reinforced Concrete Beams Using Fasteners and Fibre-Reinforced Polymer Strips" ACI Structural Journal, vol. 98, no. 3.

(15) Hadi, M. N. S. (2003): "Retrofitting of shear failed reinforced concrete beams Composite Structures". Journal of Composite Structures (Elsevier), vol. 62 (2003), pp. 1-6. doi:10.1016/S0263-8223(03)00078-3

(16) Ahmad, S.; Shah, A; Nadir, A. (2006): "Rehabilitation of Concrete Structures with Carbon Fibre Reinforced Polymers (CFRP)". Proceedings Earth \& Space Conference-2006, American Society of Civil Engineers (ASCE) Houston USA.

(17) Khalifa, A. M. (1996): "Shear Performance of Reinforced concrete beams strengthened with advanced composites". PhD thesis, Alexandria University faculty of Engineering, Egypt (www.cies.umr.edu).

(18) Bourged, M.; Delmas, Y. and Toutlemondd, F. (2001): "Experimental study of the behavior of Reinforced high strength concrete short corbels". Materials and Structures, vol. 34, pp. 155-162. doi:10.1007/BF02480506

(19) Campione, G.; La Mendola, L. and Papia, M. (2005): "Flexural behavior of concrete corbels containing steel fibres or wrapped with FRP sheets". Materials and Structures 38 (July 2005), pp. 617-625.

(20) Fattuhi, N. I. and Hughes, B. P. (1989): "Reinforced steel fibre concrete corbels with various shear span-to-depth-ratios". ACI Structures Journal, vol. 86, pp. 590-596.

(21) Fattuhi, N. I. and Hughes, B. P. (1989): "Ductility of reinforced concrete corbels containing either steel fibres or stirrups". ACI Struct. Journal, vol. 86, pp. 644-651.

(22) Elgwady, A. M.; Rabie, M.; Mohamed, T. (2005): "Strengthening of Corbels using CFRP-An experimental program". Cairo University, Giza, Egypt.

(23) Oehlers, D. J. and Moran, J. P. (1990): "Premature failure of Externally Plated Reinforced Concrete beams". Journal of Structural Engineering, ASCE vol. 116, pp. 978-995.

(24) Hutchinson, R.; Tadros, G.; Kroman, J. and Rizkalla, S.: "Use of Externally Bonded FRP Systems for Rehabilitation of Bridges in Western Canada", ACi Special Publications, SP-215, November 2003.

(25) Nanni, A. (2000): "Carbon fibres in Civil Structures: Rehabilitation and New Construction", Proc., The Global Outlook for Carbon Fibre 2000, Intertech, San Antonio, Texas, December 4-6, 2000.

(26) Yousef A. Al-Salloum and Tarek H. Almusallam (2003): "Rehabilitation of the Infrastructure Using Composite Materials: Overview and Applications". Journal of King Saud University, vol. 16 Engineering Science, pp. 1-21. 